EESTI NSV TEADUSTE AKADEEMIA TOIMETISED. X KOIDE

FOOSIKALIS-MATEMAATILISTE JA TEHNILISTE TEADUSTE SEERIA. 1961, NR. 3

ИЗВЕСТИЯ АКАДЕМИИ НАУК ЭСТОНСКОИ ССР. ТОМ Х СЕРИЯ ФИЗИКО-МАТЕМАТИЧЕСКИХ И ТЕХНИЧЕСКИХ НАУК. 1961, №3 3

\title{
МИНЕРАЛОГИЯ МОРЕН ЭСТОНИИ
}

\section{A. РАУКАС}

Изучение минералогического состава моренных отложений может оказать существенную помощь при разрешении вопросов стратиграфии ледниковых отложений и выяснении палеогеографических условий антропогенового (четвертичного) периода, а также при попсках полезных ископаемых. До последнего времени специальные нсследования минералогического состава морен Эстонии не были проведены, и настоящая работа является лишь первым шагом в этом направленин.

Для выяснения закономерностей распределения различных минералов и минеральных групп автор обратил главное внимание на фракцию, 0,1-0,25 мм, которая хорошо сепарируется в тяжелых жидкостях, легко поддается минералогическому определению и имеет в морене широкое распространение. Выбор этой фракции был обусловлен еще и тем, что автор в большинстве случаев использовал материалы, собранные и ранее гранулометрически обработанные профессором К. К. Орвику, из которых благодаря применявшейся методике фракция менее 0,1 мм часто была вымыта.

Автор выполнил полным иммерснонным методом 86 минералогических анализов по фракции $0,25-0,1$ мм и 12 анализов по фракции $0,1-0,01$ мм. О минералогии более мелких фракций дают представление 10 термических анализов, осуществленных во время исследования. Для разделения тяжелых минералов была использована жид-

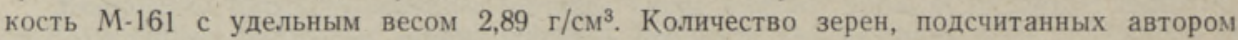
согласно рекомендациям А. Б. Вистелиуса $\left[{ }^{2}\right]$, колебалось в пределах $400-500$, а в богатых рудными минералами препаратах доходило до 1000.

Морены Эстонии характеризуются большой качественной пестротой, В целом в алевритовой и мелкопесчаной фракциях автор определил 51 различный минерал и минеральную группу. Среди них преобладают кварц, полевые шпаты и карбонаты, составляющие более 95 вес. \% всех анализируемых минералов. Содержание слюд обычно не превышает 2-3\%. На долю всех остальных минералов остается всего около $2 \%$.

Содержание тяжелой фракции (с удельным весом $>2,89$ г/см³) в моренах Эстонии невелико. В мелкопесчаной фракцин $(0,1-0,25$ мм) среднее содержание тяжелой фракции составляет лишь $0,66 \%$, причем весовое количество тяжелых минералов незначительно повышается как в сторону алевритовых, так и в сторону более крупных фракций.

В распределении тяжелых минералов по территории республики сколько-нибудь ясной закономерности не наблюдается (фиг. 1). В связи с большим содепжанием пирнта сравнительно высокие значения тяжелой фракции имеет предглинтовая синевато-серая морена (среднее из 6 анализов - 1,19\%*). Серая морена, развитая в се-

* Данные приводятся для фракции $0,1-0,25$ мм. 


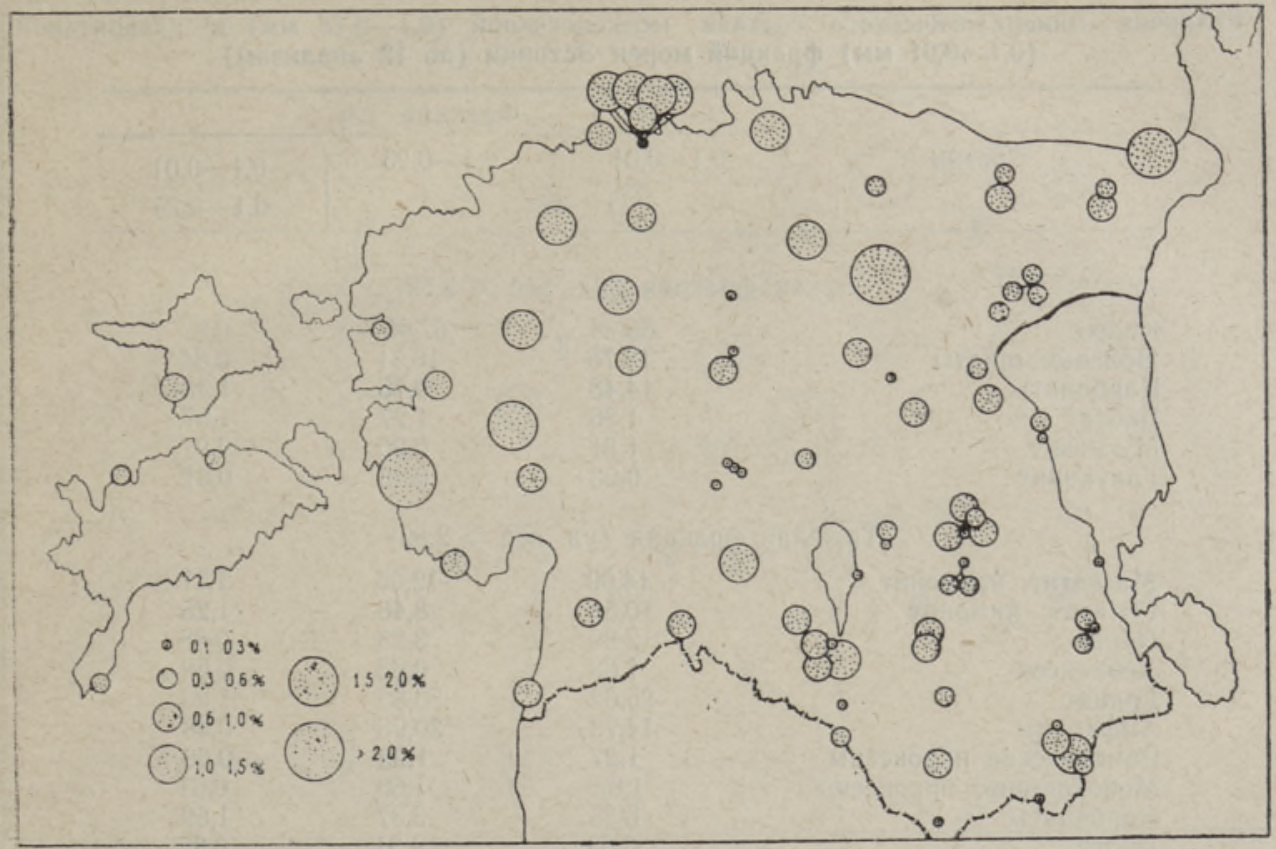

Фиг. 1. Весовое содержание тяжелых минералов (в \%) во фракции $0,1-0,25$ мм в моренах республики.

верной Эстонии, в свою очередь, содержит больше тяжелых минералов (среднее из 31 анализа - 0,83\%), чем лежащая на девонских коренных породах красно-бурая и фнолетово-серая морены (среднее из 45 анализов - 0,5\%). Все установленные макснмумы содержания тяжелых минералов (Ватла - 3,5, Вяйке-Маарья - 2,1, Вайвара $-1,95$, Энге $-1,89 \%)$ связаны с серыми типами морены.

Качественный состав минералов фракции 0,25-0,1 мм почти не отличается от качєственного состава минералов фракции $0,1-0,01$ мм. В алевритовой фракции пока не установлено присутствия оливина, а в мелкопесчаной фракции - касситерита Во фракциях размером более 0,25 мм качественный состав минералов обедняется, особенно за счет исчезновения акцессорных минералов.

Резкие отличия в различных размерных фракциях наблюдаются в количественном распространении отдельных минералов (табл. 1).

Среди минералов легкой фракции отчетливо проявляется преобладание карбонатов в более мелких фракциях, обусловленное невысокой механической устойчивостью исходного материала. Небольшой механической прочностью объясняется также накопленне биотита, мусковита и хлоритов в более мелких фракциях. Здесь необходимо еще отметить, что бесцветная слюда часто представлена серицитом, который является, продуктом разложения полевых шпатов и слюд и уже в момент возникновения встречается в виде мелких чешуек. Содержание основных минералов фракции кварца и полевых шпатов - остается, в общем, постоянным, колеблясь в небольших пределах.

Среди минералов тяжелой фракцни наиболее заметно резкое увеличение содержания циркона, монацита и ксенотима в сторону алевритовых фракций. Возрастает также содержание флюорита, топаза, апатита, анатаза, брукита и рутила. Все эти минералы являются акцессорными для материнских пород массива Фенноскандии и встречаются в них обычно в виде микроскопических кристаллов и выделений. Этим обстоятельством и объясняется концентрация их в более мелких фракциях морен. 
Различия минералогического состава мелкопесчаной $(0,1-0,25$ мм) и алевритовой $(0,1-0,01$ мм) фракций морен Эстонии (по 12 анализам)

\begin{tabular}{l|l|l|l|l}
\hline \multirow{2}{*}{ Состав } & \multicolumn{4}{|c}{ Фракции, мм } \\
\cline { 2 - 4 } & $0,1-0,01$ & $0,1-0,25$ & $0,1-0,01$ \\
\cline { 2 - 4 } & & $\%$ & & $0,1-0,25$ \\
\hline
\end{tabular}

Кварц
Полевые шпаты
Карбонаты
Биотит
Мусковит
Глауконит

Легкая фракция (уд. вес $<2,89$ )

$\begin{array}{rr}65,75 & 67,96 \\ 13,75 & 16,31 \\ 14,48 & 9,76 \\ 1,36 & 1,27 \\ 1,81 & 0,90 \\ 0,23 & 0,45\end{array}$

Тяжелая фракция (уд. вес $>2,89$ )

$\begin{array}{lrrr}\text { Магнетит, нльменит } & 14,09 & 12,05 & 1,17 \\ \text { Гематит, лимонит } & 10,58 & 8,46 & 1,25 \\ \text { Пирит } & 2,90 & 3,29 & 0,88 \\ \text { Лейкоксен } & 1,68 & 0,65 & 2,58 \\ \text { Гранат } & 25,62 & 20,85 & 1,23 \\ \text { Амфиболы } & 14,73 & 30,98 & 0,48 \\ \text { Ромбические пироксены } & 1,27 & 1,92 & 0,66 \\ \text { Моноклинные пироксены } & 1,02 & 1,66 & 0,61 \\ \text { Карбонаты } & 5,35 & 3,37 & 1,59 \\ \text { Бнотит } & 3,65 & 4,31 & 0,85 \\ \text { Мусковит } & 2,87 & 1,44 & 1,99 \\ \text { Хлориты } & 1,23 & 1,05 & 1,17 \\ \text { Монацит } & 0,58 & 0,16 & 3,62 \\ \text { Циркон } & 6,20 & 0,78 & 7,95 \\ \text { Ксенотим } & 0,07 & 0,01 & \\ \text { Турмалин } & 0,60 & 0,95 & 0,63 \\ \text { Эпидот } & 0,56 & 0,60 & 0,93 \\ \text { Шонзит, клиноцоизнт } & 0,18 & 0,32 & 0,56 \\ \text { Рутил } & 0,28 & 0,16 & 1,75 \\ \text { Титанит } & 0,27 & 0,21 & 1,28 \\ \text { Ставролит } & 0,07 & 0,30 & \\ \text { Андалузит } & 0,22 & 0,20 & 1,10 \\ \text { Дистен } & 0,27 & 0,42 & 0,64 \\ \text { Силлиманит } & 0,22 & 0,24 & 0,92 \\ \text { Апатит } & 1,28 & 0,75 & 1,71 \\ \text { Флюорит } & 0,08 & 0,03 & \\ \text { Топаз } & 0,18 & 0,10 & \\ \text { Содержание тяжелой фракции } & 0,79 & 0,61 & 1,29 \\ & & & \end{array}$

Амфиболы, пироксены, дистен, силлиманит, ставролит и глауконит вступают в процесс транспоргировки в виде более крупных обломков и, следовательно, концентрируются в более крупных фракциях морен.

Относительное повышение содержания граната и рудных минералов в алевритовых фракциях во многом обусловлено уменьшением в этих фракциях количества других часто встречающихся минералов, в частности амфиболов.

Не увязывается с теоретическими соображениями и данными других авторов [3,4] обнаруженное увеличение содержания группы эпидота в сторону более крупных фракций.

В качественном минералогическом составе морен не наблюдается сколько-нибудь более ясных различий в анализах, собранных из различных регионов республики. Более наглядные закономерности выявляются в количественных соотношениях, зависящих от влияния подстилающих пород, а также от воздействия механического и химического выветривания на обломки, слагающие морену. При этом необходимо отметить, 


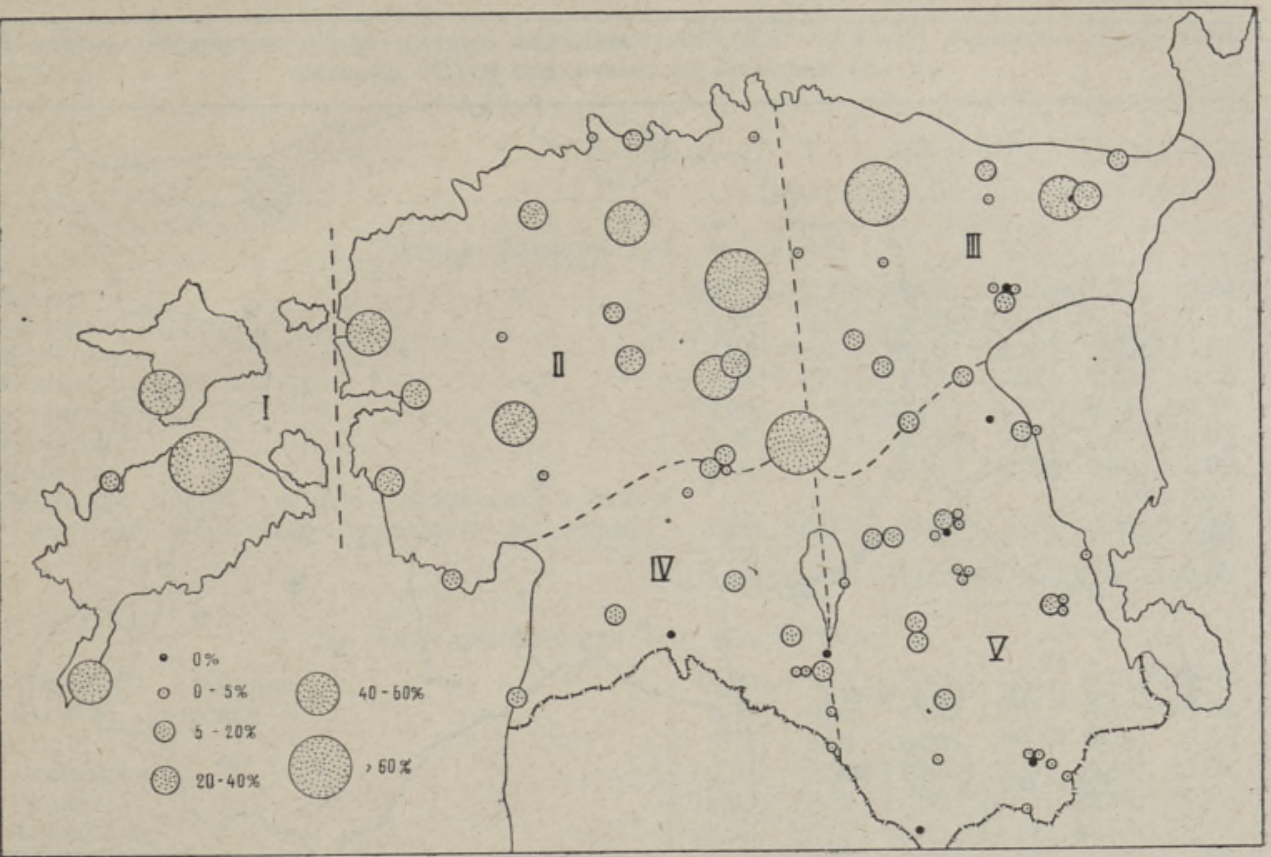

Фиг. 2. Содержание карбонатных минералов (в \%) в мелкопесчаной $(0,1-$ 0,25 мм) легкой фракции морен.

что зависимость минералогического состава песчаной и алевритовой фракции от подстилающих коренных пород выражена менее отчетливо, чем у грубообломочного материала.

Нанболее показательно уменьшение содержания карбонатных минералов в морене по мере перехода от подстилающих ордовикских и силурийских коренных пород в северной к девонским в южной части республики (фиг. 2). Если песчаная фракция североэстонской морены содержит обычно 20-70\% карбонатных минералов, то в моренах южной Эстонии содержание их редко превышает 10\%. Часто карбонаты совсем отсутствуют.

В соответствии с уменьшением содержания карбонатов в южном направленин происходит постепенное обогащение морены кварцем и полевыми шпатами, причем содержание первого возрастает быстрее, чем вторых. Это вызвано двумя причинами: 1) влиянием девонских песчаников, в которых кварц резко преобладает над полевыми шпатами, 2) механическим и химическим выветриванием полевых шпатов в ходе транспортировки.

Кроме вышеназванных, имеетя еще целый ряд закономерностей в территориальном распределении минералов. Так, рудные минералы более распространены в восточной Эстонии (среднее содержание в мелкопесчаной тяжелой фракции 32,02\% против $26,29 \%$ в западной), особенно вблизи Чудского озера.

Исключительно резкие колебания наблюдаются в распределении пирита. Если среднее содержание этого минерала в мелкопесчаной тяжелой фракции для всей реснублики составляет $5,17 \%$, то это зависит главным образом от высокого содержания пирита в предглинтовой синевато-серой морене (в среднем 32,19\%). Достаточно высокое содержание пирита отмечается также в некоторых серых моренах западных островов (Мынту - 14,50\%) и близ северного побережья (Пяртлиорг - 18,81\%). В остальных частях республики пирит в моренах либо совсем отсутствует, либо содержание его не превосходит $1-2 \%$. Такое территориальное распределение его 


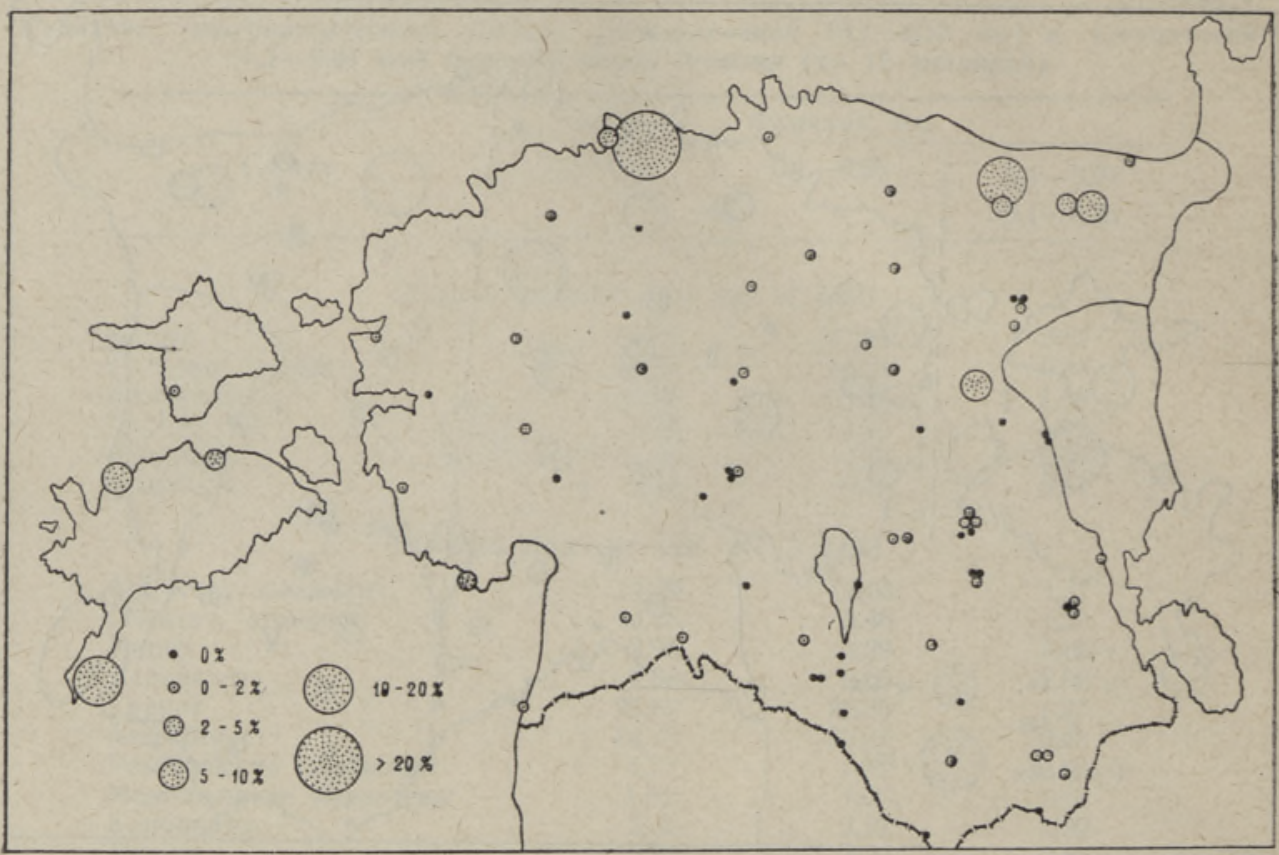

Фиг. 3. Содержанне пнрита (в \%) в мелкопесчаной $(0,1-0,25$ мм) тяжелой фракции морен.

(фиг. 3) указывает на то, что пирнт в наших моренах является пренмущественно аллохтигенным и связан с кембрийскими, нижнеордовикскими и силурийскими (яаниский горизонт) коренными породами, которые часто обогащены пиритом.

Аналогичные закономерности распределения отмечаются и у других минералов; их характеристика будет дана в описательной части.

В табл. 2 приведены сводные данные для мелкопесчаной $(0,1-0,25$ мм) фракции морен всей Эстонин и различных ее регионов, которые также наглядно показывают пзменения минералогического состава морен в различных частях республикн. Границы регионов указаны на фиг. 2 пунктиром. Регион I охватывает наши западные острова. Границы между остальными регионами совпадают с границей силура и девона н направлением Выртсъярвеской впадины. Регионы увязаны с ареалами распространення эрратических валунов, выделенными Х. Вийдингом [ $\left.{ }^{1}\right]$.

При минералогической характеристике морен республики необходимо выделить в особую группу так называемую локальную морену («рнхк»), которая широко распространена на ордовикских и силурийских породах северной Эстонин и в меньшей степени в южной Эстонии. Мелкозем североэстонской локальной морены нередко почти полностью (во фракции 0,1-0,25 мм 95-99\%) состоит из карбонатных минералов, а в южной Эстонии незначительно отличается от минералогического состава ннжележащих песчаников. При вычислении средних данных для всей республики, дабы не искажать их, локальные морены не учитывались.

Закономерности распределения минералов создают предпосылки для успешного разрешения вопросов стратиграфии. Автором установлено [.], что некоторые наши разновозрастные морены по своему минералогическому составу существенно отличаются друг от друга. Однако эти вопросы требуют дальнейших углубленных исследований.

Все описываемые минералы как по количеству, так и по своему стратиграфическому значению далеко не равноценны. Кварц, полевые шпаты, карбонаты, слюды, 
Таблица 2

Сводные минералогические данные мелкопесчаной $(0,1-0,25$ мм) фракции морен всей Әстонии (C) и различных ее регионов (I-V)

\begin{tabular}{l|l|l|l|l|l|l|l}
\hline Состав & C & I & II & III & IV & V \\
\hline
\end{tabular}

Легкая фракция (уд. вес $<2,89$ )

Кварц

Полевые шпаты

Карбонаты

Биотит

Мусковит

Глауконит

Хлориты

Обломки пород, снльно выветрелые минеральные агрегаты и остальные минералы

\begin{tabular}{r|r|r|r|r|r|r}
\hline 63,93 & 45,79 & 59,08 & 58,28 & 75,77 & 78,84 \\
14,89 & 9,30 & 9,68 & 24,97 & 15,72 & 14,32 \\
17,01 & 42,71 & 18,99 & 12,20 & 6,05 & 4,67 \\
1,16 & 0,57 & 1,72 & 1,37 & 1,10 & 1,02 \\
0,96 & 0,64 & 0,73 & 1,97 & 0,84 & 0,61 \\
0,75 & - & 3,62 & 0,07 & 0,03 & 0,03 \\
0,06 & - & 0,15 & 0,09 & 0,06 & 0,02 \\
& & & & & \\
1,79 & 0,99 & 6,03 & 1,05 & 0,43 & 0,49 \\
\hline
\end{tabular}

Тяжелая фракция (уд. вес $>2,89$ )

Магнетит, ильменит

Гематит, лимонит

Пирит

Лейкоксен

Гранат

Амфиболы

Ромбические пироксены

Моноклннные пироксены

Оливнн

Биотит

Карбонаты

Мусковнт

Глауконит

Хлориты

Циркон

Монацит

Ксенотим

Турмалин

Эпидот

Цоизит, клиноцоизнт

Рутил

Титанит

Ставролит

Андалузит

Дистен

Силлиманит

Апатит

Toпаз

Корунд

Остальные

Содержание тяжелой фракции

Число анализов

\begin{tabular}{|c|c|c|c|c|c|}
\hline 14,23 & 15,14 & 10,65 & 17,88 & 9,56 & 17,49 \\
\hline 9,14 & 9,36 & 4,86 & 11,91 & 9,37 & 10,26 \\
\hline 5,17 & 6,04 & 16,36 & 2,49 & 0,28 & 0,68 \\
\hline 1,07 & 0,52 & 0,64 & 1,25 & 0,86 & 2,09 \\
\hline 19,63 & 13,22 & 17,98 & 22,53 & 22,46 & 21,72 \\
\hline 28,63 & 30,15 & 25,33 & 25,34 & 34,33 & 27,32 \\
\hline 1,91 & 2,82 & 1,75 & 1,80 & 1,84 & 1,38 \\
\hline 1,55 & 2,63 & 1,37 & 1,25 & 1,39 & 1,09 \\
\hline 0,03 & 0,05 & 0,04 & 0,91 & $\mathrm{C}, 04$ & $<0.01$ \\
\hline 3,67 & 5,88 & 2,72 & 3,17 & 3,88 & 2,66 \\
\hline 2,78 & 4,86 & 2,69 & 2,21 & 1,59 & 2,51 \\
\hline 0,74 & 0,47 & 0,12 & 0,81 & 1,66 & 0,65 \\
\hline 0,11 & - & 0,51 & - & 0,03 & 0,03 \\
\hline 0,70 & 0,98 & 0,73 & 1,19 & 0,91 & 0,71 \\
\hline 1,21 & 0,65 & 0,57 & 1,62 & 0,86 & 2,34 \\
\hline 0,15 & 0,05 & 0,10 & 0,23 & 0.12 & 0.25 \\
\hline 0,03 & -- & 0.01 & 0,03 & 0,02 & 0,08 \\
\hline 0,86 & 0,36 & 0.56 & 0,70 & 1,34 & 1,41 \\
\hline 0,81 & 1,04 & 0.54 & 0,96 & 0,76 & 0,76 \\
\hline 0,33 & 0,75 & 0.29 & 0,13 & 0,30 & 0,16 \\
\hline 0,21 & 0,06 & 0,26 & 0,19 & 20 & 0,34 \\
\hline 0,24 & 0,12 & 0,11 & 0,36 & 19 & 0,43 \\
\hline 0,24 & 0,06 & 0,26 & 0,25 & 0,26 & 0,37 \\
\hline 0,31 & 0,17 & 0,13 & 0,68 & 0,23 & 0.33 \\
\hline 0 , & 0,28 & 0,4 & 0,26 & 0,07 & 0.27 \\
\hline & 0,17 & 0,0 & 0,20 & & 0.1 \\
\hline & 0,58 & 0,5 & 0,82 & 0,80 & 0.8 \\
\hline & 0,20 & 0,1 & 0,03 & 0,14 & 0,1 : \\
\hline & 0,06 & & 0,10 & 0,10 & 0,17 \\
\hline & 3,33 & 10,09 & 1,60 & 6,20 & 3,37 \\
\hline
\end{tabular}

амфиболы, гранаты и рудные минералы всегда представлены многочисленными зернами и составляют около $99,9 \%$ всех опнсываемых минералов. Обычными являются также пироксены, хлориты, циркон, турмалин, апатит и минералы группы эпидота. Единичными зернами представлены рутил, титанит, брукит, анатаз, ставролит, дистен, андалузит, силлиманит и монацит, реже топаз и корунд. А такие минералы, как гипс, кордиерит, оливин, касситерит, ортит, ксенотим и флюорит, обнаруживаются лишь в виде отдельных (редких) находок. 
Наибольшее стратиграфнческое значение, по всей вероятности, имеют карбонаты, пирнт и различные амфиболы. Интересные результаты могут дать также наблюдення над полевыми шпатами, слюдами, пироксенами, глауконитом, цирконом и турмалином. Остальные минералы для стратиграфических выводов либо слишком малочислены, либо распределяются равномерно.

Ниже приводится краткое опнсание минералов, встречающихся в мелкопесчаной и алевритовой фракциях морен, вместе с закономерностями их распространения. Прн этом процентные данные приведены только для мелкопесчаной $(0,1-0,25$ мм) фракции.

В первую очередь остановимся на минералах легкой фракции и на минералах, встречающихся и в легкой, и в тяжелой фракциях. Затем следуют минералы тяжелой фракции.

Кварц является нанболее распространенным минералом песчаной и алевритовой фракций морен Эстонии. Даже в богатых карбонатами-моренах северной Эстонин содержание его обычно не опускается ниже $50 \%$, а в юго-восточной части республики достигает 80 , иногда даже $95 \%$ всей мелкопесчаной фракции. Зерна кварца могут иметь разнообразную форму, но обычно они встречаются в виде угловато-окатанных зерен неправильной формы. В южной и юго-восточной частях республики наблюдается увеличение окатанности кварцевых зерен. Коэффициент окатанности по трехбальной системе (1 - угловатые, 2 - полуокатанные и 3 - окатанные зерна) составляет для северных районов республики от 1,68 до 2,00 , для средней Эстонии от 1,88 до 2,22 и для юго-восточной Эстонии от 1,88 до 2,32 . Увеличение окатанности кварцевых зерен в моренах совпадает с направлением движения материкового льда во время последнего оледенения и с повышением окатанности минеральных зерен в девонских песчаниках (по данным А. Тамме). Часто зерна кварца покрыты гидроокислами железа и содержат в большом количестве включения, наиболее частыми из которых являются слюды, рутил, циркон, апатит и рудные минералы, а также жидкостные включения с газовыми пузырьками. Иногда зерна слабо катаклазированы и обладают волнистым погасанием, В некоторых обнажениях (Мехикоорма, Вескитагузе и др.) встречаются дипирамидальные доросшие новообразования кварца хорошей кристаллической формы с окатанным ядром.

Полевые шпаты представлены группой плагиоклаза, ортоклаза и микроклин а. Обычно содержание полевых шпатов колеблется от 9 до 25\% и только в редких случаях превосходит $40 \%$ (Койги, Кынну), Среди полевых шпатов преобладает ортоклаз. Плагиоклазы, судя по показателю преломления и углу погасания, представлены главным образом олигоклазом и олигоклаз - альбитом. Основные глагиоклазы встречаются очень редко. Наименьшее распространение имеет решетчатый микроклин, хотя он присутствует в большинстве исследованных образцов.

Форма зерен полевых шпатов угловато-округлая или таблитчатая; поверхность зерен часто пелитизирована, реже серицитизирована или покрыта гидроокислами железа. Следует отметить, что быстрее всего поддаются выветриванию кристаллы основного плагиоклаза, затем ортоклаза. Лучше других противостоят выветриванию кристаллы микроклина. Часто можно наблюдать, что среди снльно выветрелых зерен ортоклаза, плагиоклаза и слюдисто-глинистых агрегатов встречаются почти не выветрелые кристаллы микроклина.

Карбонаты піо количественному содержанию стоят на, втором месте после кварца. Среди них резко преобладают зерна кальцита и доломита. Очень редко встречаются кристаллы сид ерита. Обычно карбонаты наблюдаются в виде неправильных, слегка округленных зерен. Нередки также хорошо образованные ромбоэдры, особенно у доломита. Иногда на пластинках кальцита наблюдается двойниковая штриховка.

Биотит является частым минералом как в тяжелой, так и в легкой фракциях морен. Содержание его колеблется в больших пределах: наиболее часто оно равно $0,5-2 \%$, иногда $6-7 \%$ (Тарту, Вяйке-Маарья) и доходит до $21 \%$ (Ватла). Встречается главным образом в виде бурых и желтовато-бурых, реже зеленоватых пла- 
стинок по спайности. Часто содержит включения рутила, циркона, апатита и других минералов, вокруг которых иногда наблюдаются плеохроичные дворики. Встречаются мластинки с рудной вкрапленностью и с примазками окислов железа, реже наблюдается разложение бнотита с обильным выделением окислов железа или полная опацитизация его. Нередко наблюдаются также всевозможные переходы от биотита к хлориту.

Содержание мусковита колеблется в моренах в меньших пределах, чем содержание биотита. Присутствует в большинстве исследуемых анализов с максимумом $\mathbf{3}$ легкой или в тяжелой фракции, но количество его редко превосходит $1,5-2,0 \%$. Обычно встречается в виде тонких бесцветных или слабо-желтоватых листочков по (001), овальной или полуовальной, реже неправильной формы. Нередко в листочках мусковита наблюдаются включения других минералов, главным образом циркона и рутила. В сильно выветрелых моренах чешуйки мусковита обычно переходят в серицитоподобные агрегаты.

Глауконит. Однночные зерна глауконита можно найти по всей территории Эстонии. Ясная тенденция к концентрации глауконита наблюдается в предглинтовой синеватосерой морене и в моренах близ глинта, где содержание глауконита в мелкопесчаной фракщии может достигать 15-17\% (Маарду). Это вполне объяснимо влиянием богатых глауконитом местных нижнеордовикских пород (онтикаский ярус). Глауконит обычно встречается среди минералов легкой фракции, но он не редок и в тяжелой фракцин. Для него характерны комковатые, округленные или неправильные зерна тонковолокнистого и тонкоагрегатного сложения темно-зеленого цвета. При наблюдении в поляризованном свете отчетливо заметен плеохроизм отдельных кристаллов, придающий зерну мозаичный вид.

Хлорит. Обынно является продуктом разложения биотита, амфиболов и пироксенов. Встречается главным образом в виде округленно-угловатых, лишенных кристаллографических очертаний пластинок нежно-зеленой, синевато-зеленой нли сероватой окраски с тусклыми аномальными интерференционными цветами. Нередко отмечаются включения, особенно рудных минералов.

Гипс в моренах Әстонии встречается очень редко. До сих пор обнаружен только в двух местонахождениях, в серых разновидностях морены (Мыдрику, Койги), в виде одиночных кристаллов. Встречается в виде бесцветных, хорошо образованных крнсталлов.

Из сульфатных минералов единичными кристаллами обнаруживается также барит.

Кордиерит. Точно установлен пока лишь в одном местонахождении (Мехикоорма), где встречен в виде округленно-угловатого, почти бесцветного, слабо плеохроирующего в желтых тонах зерна с мелкими включениями (циркона, рутила?), вокруг которых отмечаются плеохроичные дворики.

Амфиболы являются самыми распространенными минералами в тяжелой фракции морен республики. Среди них наблюдается большое разнообразие. Преобладает о быкновенная рогов я обманка зеленого, буровато-зеленого или буроватого, реже синеватого цвета со слабо выраженным плеохроизмом. Форма зерен удлиненно-шестоватая, призшатическая с неровными краями, таблитчатая, угловатоокруглая, обычно с плохо выраженной спайностью. Включения наблюдаются редко и представлены главным образом рудными мннералами, реже рутилом или апатитом. Иногда наблюдается полная опацитизация. Облик зерен чаще всего свежий, но изредка отмечается замещение роговой обманки хлоритом, гораздо реже биотитом или эпидотом. Нередко в моренах присутствует грязно-зеленый у р али т, в зернах которого иной раз наблюдаются реликты спайности пироксена, реже сохраняется восьмиугольная форма их.

Среди амфиболов постоянно встречаются щелочные разновидности, хотя содержание их обычно не превышает $1-2 \%$ от всей тяжелой фракции. Для них (кроме глаукофана) характерен сильный плеохроизм по турмалиновой схеме абсорбции от темно-бурого (почти черного) до зеленого, от темно-зеленого до светло-бурого и т. д., а для глаукофана от индиго-синего (через фиолетовый) до почти бесцветного или 
серовато-зеленого цвета. Глаукофан обычно встречается в виде удлиненных (иногда зазубренных) неправильных зерен. Для других щелочных амфиболов (ар фведсонит, рибекит) более характерен таблитчатый и угловато-округленный габитус.

В большинстве местонахождений присутствуют также бесцветные или слабоокрашенные разновидности амфиболов типа антофиллита, актинолита, тре молита. Встречаются они преимущественно в виде вытянутых призматических и волокнистых (антофиллит, актинолит) нли неправильных с сильно зазубренными краями зерен (тремолит). Все названные разновидности неплеохроичны или плеохроируюr слабо. Включения редки. Угол погасания мал и не превышает $20^{\circ}$, причем антофиллит в большинстве случаев имеет прямое погасание.

Базальтические роговые обманки в моренах Эстонии редки.

Пироксены достаточно распространены в моренах. Содержание их в тяжелой фракции колеблется от 1 до $11 \%$ (Селисте), составляя в большинстве случаев $3-5 \%$. Содержание пироксенов несколько увеличивается в сторону западных районов республики, имея особенно широкое распространение на западных островах. Интересно от метить, что в этом направлении увеличивается также количество минералов группь амфибола и эрратических валунов основного состава [1].

Ромбические и моноклинные пироксены встречаются почти в равных количествах, причем более часты все же ромбические пироксены. Иногда моноклинные пироксены могут в анализах совсем отсутствовать. Среди ромбических пироксенов преобладает ги перстен с ясно выраженным плеохроизмом от розового, мясно-красного, бурого, желтовато-бурого до зеленого или серовато-зеленого цвета. Форма зерен короткопризматическая, с неровными краями. Некоторые зерна бывают и идиоморфные. Часто наблюдается спайность по (110), иногда обильное содержание мелких включений окислов железа или биотита, расположенных вдоль зерна нли в шахматном порядке. Некоторые гиперстены, как и другие ромбические пироксены, нмеют относнтельно удлинения небольшое (до $10^{\circ}$ ) косое погасание.

Бесцветный или серовато-зеленый энстатит встречается в моренах гораздо реже, чем гиперстен. Характеризуется неправильной или коротко-призматической формой и отсутствием плеохроизма. Включения различных минералов (магнетит, апатит, циркон) обычны.

Среди моноклинных пироксенов преобладают а в ит и ди п п ид. Встречаются они почти в равных количествах. Для обоих характерен коротко-призматический, реже таблитчатый или листоватый бесформенный габитус (нередко с зазубреннымн краями), большой угол погасания, хорошо наблюдаемая спайность и неплеохроичность. Отличается диопсид от авгита главным образом цветом. Днопсид обычно бесцветный, бледно-зеленый и серый, тогда как авгиту свойственны более темные, зеленые или бурые оттенки. Отличительным признаком авгита служит также больший показатель светопреломления и угол погасания.

Иногда наблюдается частичное замещение пироксенов амфиболом, а также серпентинизация и опацитизация их.

Гранаты широко распространены в тяжелой фракции морен. В алевритовой фракции они занимают по общему количеству первое место, а в мелкопесчаной фракции стоят на втором месте после амфиболов. Встречаются главным образом в виде совершенно свежих, неправнльно остроугольных изотропных обломков с раковистым или неровным изломом, не обнаруживающих плоскостей спайности или поверхностей граней. Нередко зерна слабо окатаны. Хорошо ограненные кристаллы очень редки. Обычно бесцветны, реже окрашены в розовые, красные или слабые зеленоватые или желтоватые тона. Судя по цвету и показателю преломления, среди гранатов преобладает альмандин. Некоторые зерна (около 1-5\%) носят на поверхности характерғые следы растворения (черепитчатая поверхность, частые выемки и пятна) или содержат обильные включения (кварца, цнркона, рудных минералов, жидкостей и т. д.). 
Интересно еще отметить, что включения и формы растворения в большинстве случаев связаны с окрашенными разновндностями гранатов.

Циркон постоянно присутствует в тяжелой фракции морен. Максимальное количество циркона доходит в мелкопесчаной фракции до $6-7 \%$, а в алевритовой фракцни - до $25 \%$. Наибольшая концентрация его наблюдается в юго-восточной части республики в связи с относительно высоким содержанием этого минерала в девонских песчаниках этого региона (по данным X. Вийдинга).

Преобладающим типом циркона являются бесцветные призматические зерна, которые часто значительно окатаны. Реже встречаются желтые, бурые, розовые, краснобурые и зеленоватые разновидности. Окрашенные разновидности слабо плеохроируют, Окатанность зерен циркона увеличивается в юго-восточном направлении в соответствии с увеличением окатанности зерен в девонских песчаниках и движением материкового льда. Для циркона характерно обнльное содержание различных включений (жндкостных, газовых, кристаллических; из последних наиболее часты апатит, рутил, рудные минералы и др.). Часто включения ориентированы вдоль призмы. Иногда отчетливо заметно зональное строение кристаллов. Редкие зерна с трещинами. В некоторых сечениях зерна циркона имеют косое погасание.

Монацит и особенно ксенотим встречаются в моренах Эстонии весьма редко. Содержание их только в единичных случаях превышает $1 \%$ тяжелой фракции. Қак циркон, так и монацит с ксенотимом наиболее распространены в юго-восточной части республикн. Обычно встречаются в виде хорошо окатанных или яйцевидных бледно-желтых зерен, но не редки бесцветные, оранжевые, розовые и бурые разновидности. Идиоморфные кристаллы не часты. Окрашенные зерна слабо плеохроируют. В отличие от циркона включения в монаците и ксенотиме редки или отсутствуют. Зонального строения кристаллов не наблюдается.

Турмалин присутствует почти во всех просмотренных анализах, но обычно в небольших количествах. Только в немногих случаях содержание турмалина в тяжелой фракцин превосходит 2-3\%. Содержание в моренах южной Эстонии турмалина значительно выше, чем в моренах северной Эстонии, что объясняется влиянием подстилающих девонских песчаников.

Турмалин отличается исключительным разнообразием окраски. Чаще всего встречаются зеленовато-бурые разновидности. Иногда отмечается различная окраска отдельных участков одного и того же кристалла. Зерна турмалина сильно плеохронруют во всевозможных тонах (бурый, зеленый, желтый, коричневый, розовый, фнолетовый, черный, бесцветный, синий). Очень редко наблюдаются неплеохроичные бесцветные разновидности турмалина.

По форме различаются два главных типа турмалина, распространенные в моренах: 1) неокатанные или слабоокатанные коротко-призматнческие зерна с хорошей огранкой и обильным содержанием различных газовых, жидкостных и минеральных включений, которые в большинстве случаев ориентированы вдоль призмы, 2) идеально окатанные зерна обычно с небольшим содержанием включений. Полуокатанные и бесформенные зерна сравнительно редки.

Закономерности территориального изменения окатанности турмалина не выражены столь ясно, как, например, у кварща и циркона, но и здесь отмечается общее увеличение окатанности в сторону южных и юго-восточных районов республики.

Оливин в алевритовых фракциях морен пока еще совсем не обнаружен. Встречается лишь единичными зернами в песчаных фракциях. Чаще отмечается в западных районах республики, где присутствие его, вероятно, связано с влиянием массива финляндских сатакунтских оливиновых днабазов, валуны и гальки которых распространены в этих районах. Оливин встречается в виде овальных зерен, у которых частично сохранены кристаллографические очертания. По цвету нежно-зеленый или синевато-зеленый, неплеохроичный.

Эпидот, цоизит, клиноцоизит. Минералы группы эпидота имеют ограниченное распространение. Обычно содержанне нх в тяжелой фракцин не превосходит $1,5 \%$ и 
только в немногих случаях достигает $3 \%$. Наибольшее содержание минералов этой группы отмечено на западных островах республики.

Желтовато-зеленые зерна эпидота никогда не имеют идиоморфных очертаний. Форма зерен угловато-округлая, поверхность их неровная. Плеохроизм обычно выражен слабо, но некоторые зерна эпидота плеохроируют интенсивно от желтовато-зеленого до нежно-синего или бесцветного. Обладет высоким двупреломлением. Нередки включения.

Цо изит встречается главным образом в виде окатанных коротко-призматических бесцветных, серых, иногда слабо-зеленоватых зерен. Обладает слабым двупреломлением, характерными синими интерференционными цветами (не всегда!) и прямым погасанием. Плеохронзм отсутствует или выражен очень слабо.

Кл и н оцо и зи т по форме и цвету похож на цоизит. Отличается от него косым погасанием, более высоким показателем светопреломления и двупреломления. У цоизита и клиноцоизита иногда наблюдается хорошо выраженная спайность по (010) или (100).

Ортит в моренах республики очень редок. Встречается в виде слабоокатанных призматических зеленовато-бурых или желто-бурых умеренно плеохроирующих в зеленых и бурых тонах зерен.

Рутил встречается в виде зерен неправильной, угловато-округлой или округлой формы, бурого, желто-бурого, красно-бурого нли золотисто-бурого цвета с янтарным оттенком, с неровной, бугристой поверхностью, нередко со слабым плеохроизмом. Крупные кристаллы часто почти непрозрачны. Реже встречаются призматические удлиненные зерна с гладкой поверхностью, еще реже коленчатые по (101) двойники. На некоторых кристаллах наблюдается штриховка, являющаяся следствием образования полисинтетических двойников. Включения в рутиле редки.

Титанит (сфен), как и рутил, редкий минерал. Количество его в тяжелой фракции колеблется обычно в пределах $0,2-0,4 \%$ и только в немногих случаях превосходит $1 \%$. В моренах восточной Эстонии встречается чаще, чем в моренах западной Эстонии. В анализах может совершенно отсутствовать.

Зерна титанита редко имеют идиоморфные очертания, чаще встречаются обломки неправильной угловатой или окатанной формы. Титанит - буровато-желтый, желтовато-зеленый, оранжевый или бесцветный минерал со слабо выраженным плеохронзмом и матовой поверхностью. При вращении столика мнкроскопа кристаллы титанита зачастую не гаснут, а лишь меняют ннтерференционную окраску (от синего до желтого).

Другие титановые минералы - брукит и анатаз - встречаются в моренах еще реже, чем рутил и титанит (не принимая во внимание ильменита). В большинстве анализов они отсутствуют или встречаются только в виде единичных зерен среди минералов тяжелой фракции, причем содержание их никогда не достигает даже $0,5 \%$.

Бр ук и т встречается в виде неправнльных угловатых призматических или таблитчатых зерен, окрашенных в коричнево-фиолетовый, темно-бурый или желтый цвет. Обычны штрихи вдоль призмы. у большинства зерен наблюдается отсутствие погасания. Иногда заметен слабый плеохроизм.

А н а та 3 встречается либо в виде хорошо образованных таблитчатых крнсталлов квадратного габитуса и зонального строения, либо в виде слабо окатанных угловатых пластинок бурового, желтовато-коричневого, серого (почти бесцветного) или голубовато-серого цвета с гладкой поверхностью. Изредка встречаются сростки таблитчатых кристаллов. Нередко они сопровождаются тонкозернистой массой лейкоксена, особенно по краям кристаллов. В этом случае кристаллы анатаза почти непрозрачны и в отраженном свете окрашены в желтый цвет.

Касситерит встречается в моренах Эстонии только единичными зернами в виде непрозрачных просвечивающих красновато-бурых или серых призматических или неправильных зерен. На гранях кристаллов наблюдается тонкая штриховка. Встречаются включения окислов железа. 
Количество ставролита в тяжелой фракции морен редко превышает $1 \%$. Распределен почти равномерно по всей республике. Встречается в виде коротко-призматических, неправильно-угловатых или округло-угловатых зерен, обычно с остро-ребристым изломом и неправильными очертаниями. Часты разорванные края кристаллов. Цвет ставролита лимонно-желтый, буровато-желтый, зеленовато-желтый или красновато-бурый с умеренным плеохроизмом по турмалиновой схеме абсорбции. Нередко в ставролите встречаются включения. Представлены они главным образом кварцем, рутилом, гранатом, жидкостями и минеральной пылью. Поверхность зерен ставролита неровная, покрыта небольшими ямками и выпуклостями. Наблюдается спайность по (010) нли (110).

Количество дистена также невелико и в большинстве случаев не превышает $1 \%$ тяжелой фракции. Сравнительно редко наблюдается в юго-западной Эстонии, в остальных частях республики распределен более или менее равномерно. Встречается в зиде удлиненно-шестоватых или угловато-округлых призматических зерен с неправильными верхушками и хорошо заметной спайностью. Зерна дистена бесцветные, слегка голубоватые или серовато-зеленые с очень слабым плеохроизмом. Погасание обычно (вдоль призмы) под углом $\pm 30^{\circ}$. Нередко встречаются включения.

Максимальное количество андалузита не превышает 2-3\% тяжелой фракции Встречается в виде бесцветных или серых зерен разнообразной формы: обычны угловато-округлые, но- наблюдаются также и призматические и округлые. Из-за́ выветривания минерал иногда приобретает тусклый вид. Обычно наблюдается переход андалузита в слюдистое вещество (серицит, мусковит). Почти всегда наблюдается спайность по призме. Часто содержит включения углистого вещества, иногда и других минералов, жидкостей и газов, которые всегда располагаются ориентированно.

Силлиманит часто отсутствует; ни в одном проведенном до сих пор анализе содержание его не превышало $1 \%$. Представлен в внде удлиненных с неправильно ограниченными концами призм или волокон, часто изгибающихся. Обычно бесцветен, но встречаются слабо зеленоватые или бурые разновидности. В последнем случае наблюдается слабый плеохроизм. В редких случаях встречаются в виде таблитчатых бесцветных призм.

Апатит постоянно присутствует среди тажелой фракции морен. Несмотря на это, содержание его все-таки редко превышает $1,5-2,0 \%$. Более широкое распространение имеет в восточных районах республики, возможно, благодаря влиянию Выборгского массива рапакиви, где апатит является частым акцессорным минералом.

Встречается в виде бесцветных, серых или бледно-голубоватых зерен продолговатой, неправильной, часто округлой или яйцеобразной формы. Идиоморфные тонкопризматические кристаллы редки. Характеризуется очень низким двупреломлением н отсутствием спаӥности. Иногда обнаруживает отдельность в виде мелких прерывистых линий вкрест удлинения призмы. Нередко зерна апатита содержат многочисленные мелкие газовые, жидкие или игольчатые неопределимые минеральные включения, которые в большинстве случаев расположены вдоль главной оси кристалла.

Флюорит встречается в моренах в виде единичных зерен, причем не обнаруживается какой-либо определенной связи с рапакиви-массивами Финляндии, где флюорит является постоянно присутствующим акцессорным компонентом. Представлен совершенно прозрачными светло-фиолетовыми или бесцветными оптически изотропными зернами с очень низким показателем светопреломления округленно-угловатой или неправильной формы.

Топаз обычно встречается в анализах в виде немногочисленных зерен или отсутствует. Представлен чаще всего округленно-угловатыми полуокатанными бесцветными бледно-синеватыми или желтоватыми прозрачными обломками. Идиоморфные призматические кристаллы очень редки. Нередко содержит включения жидкости и рудных минералов.

Корунд встречается в виде бесцветных с неправильными очертаниями более или менее окатанных зерен с высоким показателем светопреломления и низким показа- 
телем-двупреломления. Интерференционные цвета никогда не бывают выше серого. Представлен в анализах немногочисленными зернами, нередко отсутствует.

Рудные минералы представлены в моренах магнетитом, ильменитом, гематнгом, лимонитом, пиритом и лейкоксеном. Судя по составу коренных пород нашей республики, можно предполагать присутствие галенита и сфалерита, но автором пока они не найдены.

Магнетит и ильменит обычно встречаются в виде неправильных, округленно-угловатых непрозрачных зерен темно-серого, серебристо-серого или черного цвета (в отраженном свете). У магнетита иногда обнаруживаются формы октаэдра и додекаэдра. Нередко является продуктом опацитизации различных минералов. Магнетит и ильменит различаются с большим трудом. Наиболее надежным способом различения является выделение магнетита простым магнитом. Судя по данным магнитной сепарации, ильменит значительно более распространен в моренах Эстонии, чем магнетит. Зерна его нередко частично или целиком покрыты белыми продуктами разложения (лейкоксенизация) .

Гематит наибөлее часто встречается в виде округлых или неправнльных землистых масс характерного красновато-бурого цвета в отраженном свете, иногда в виде хорошо образованных призматических зерен с великолепным блеском.

Лимонит также встречается преимущественно в виде неправильных зерен или землистых агрегатов, отличающихся в отраженном свете своим бурым нли ржавокоричневым охристым цветом. Лимонит имеет гораздо более широкое распространение, чем гематит. Часто в анализах большинство зерен покрыты тонкой пленкой лимонита так, что даже трудно поддаются определенню. Этот процесс особенно распространен в пределах распространения южноэстонской красно-бурой морены.

У пирита отмечается большое разнообразие хорошо образованных и сохранившихся кристалличчески форм. Наряду с монокристаллами (среди которых преобладают гиритоэдры и октаэдры) встречаются обломки кристаллов, а еще чаще сростки многочисленных небольших кристаллов.

В одном случае в морене установлен халькопирит (?). Возможно и прнсутствие марказита.

Лейкоксен имеет более широкое распространение в восточной части республики. Встречается в виде округлых нли угловато-округлых зерен, непрозрачных в проходящем свете и чисто-белых или слабо-желтоватых в отраженном свете. Зерна лейкоксена часто имеют агрегатное строение и шероховатую, бугристую поверхность. Является вторичным продуктом изменения минералов, содержащих титан.

Минералогический состав более тонких - размером менее 0.01 мм - фракций морен изучен пока очень слабо. Имеется лишь несколько термографических анализов, на основе которых можно сказать, что основная масса глинистых фракций предглинтовой синевато-серой и южноэстонской красно-бурой морены представлена гидрослюдами, а тонкие фракции североэстонской серой морены содержат дополнительно к этому значительную примесь карбонатных минералов. Дальнейшие исследования по этим фракциям дадут, несомненно, много интересного и являются необходнмыми для полного освещения минералогического состава морен Эстонии.

\section{ЛИТЕРАТУРА}

1. Х. Вийдинг, Распространение и петрография эрратическнх валунов Эстонской ССР. Труды регионального совещания по изучению четвертичных отложений Прибалтики и Белоруссии. Научн. сообщ. Ин-та геол. и геогр. АН Лит. ССР, Внльнюс, 1957.

2. А. Б. В истели ус, О необходимом числе зерен, подсчитываемых при иммерсии, Зап. Всес. мннералог. о-ва, $3,1951$. 
3. У. Г. Д и ст анов, О некоторых вопросах методики иммерсионных нсследований терригенной части осадочных горных пород, Зап. Всес. минералог. о-ва, 2, 1956.

4. Е. В. Рухина, Литология моренных отложений, Изд. ЛГУ, Л., 1960.

5. A. R a ukas, Mineraloogilise meetodi kasutamise võimalusest moreenide uurimisel Eestis, ENSV TA Geoloogia Instituudi Uurimused, VII, Tallinn, 1961.
Институт геологии
Академии наук Эстонской ССР
Поступила в редакцию
30. XII 1960

\section{EESTI MOREENIDE MINERALOOGIA}

\section{A. Raukas}

\section{Resümee}

Artiklis antakse Eesti moreenide mineraloogiline iseloomustus 98 immersioonimeetodil Tehtud analüüsi ja 10 termilise analüüsi alusel. Peatähelepanu on pööratud peenliivase (0,1-0,25 mm) fraktsiooni mineraalide ning nende leviku seaduspärasuste kirjeldamisele.

Aleuriitses ja peenliivases fraktsioonis on autor kindlaks teinud 51 erinevat mineraali ja mineraalirühma. Valdavateks mineraalideks on kvarts, päevakivid, karbonaadid, vilgud, amfiboolid, granaat ja maakmineraalid, mis kokku moodustavad umbes 99,9\% kôigist kindlakstehtud mineraalidest. Tabelis 2 esitatakse mineraalide protsentuaalsed sisaldused kogu vabariigi (C) ja tema erinevate regioonide kohta $(\mathrm{I}-\mathrm{V})$.

Raske fraktsiooni $\left(e>2,89 \mathrm{~g} / \mathrm{cm}^{3}\right)$ hulk analüüsides on harilikult väike ning ületab harva $1 \%$. Territoriaalselt ei esine raske fraktsiooni hulk küllalt selge seaduspärasusega (vt. joon. 1).

Tabelis 1 on 12 analüüsi alusel toodud peenliivase $(0,1-0,25 \mathrm{~mm})$ ja aleuriitse $(0,01-$ $0,1 \mathrm{~mm}$ ) fraktsiooni mineraloogilise koosseisu erinevused. Need on tingitud mineraalide mehaanilisest ja keemilisest vastupidavusest ning suurusest moreenide lähtekivimeis.

Erinevate mineraalide territoriaalses levikus esineb rida seaduspärasusi, mis loovad eeldused stratigraafiliste küsimuste edukaks lahendamiseks. Nii näiteks väheneb vabariigi Iōunarajoonide suunas seoses aluspōhja iseloomu muutumisega karbonaatide sisaldus moreenides (vt. joon. 2), suureneb aga vastavalt kvartsi ja päevakivide hulk. Püriiti esineb rohkesti neis moreenides (vt. joon. 3), kus lähedal paljanduvad püriidirikkad aluspōhja kivimid.

Ka mineraaliterade ümardus on vabariigi erinevates osades erinev. Umarduskoefitsient suureneb vabariigi lõuna- ja kagurajoonide suunas ning langeb üldjoontes kokku mandrijää liikumise suunaga ja devoni liivakivides esinevate mineraaliterade ümardusastıne suurenemisega.

Minraalidest on suurima stratigraafilise tähtsusega karbonaadid, püriit ja mitmesugused amfiboolid. Huvitavaid tulemusi võib saada ka päevakivide, vilkude, pürokseenide, glaukoniidi, tsirkooni ja turmaliini leviku jälgimisega. Ulejäänud mineraalid esinevad stratigraafiliste järelduste tegemiseks kas liiga väikestes hulkades vōi on jaotunud kogu vabasiigi territooriumi ulatuses liiga ühtlaselt. 


\section{THE MINERALOGY OF THE ESTONIAN TILLS}

\section{A. Raukas}

\section{Summary}

This mineralogical survey of the Estonian tills has been drawn up on the basis of 98 analyses using the immersion method and 10 thermic analyses. The main attention has been paid to the fine-sand fraction minerals $(0.1-0.25 \mathrm{~mm})$, and a description of their distribution pecularities is given as well.

The presence of 51 different minerals and mineral groups was ascertained in the aleurite and fine-sand fraction. The dominating minerals are quartz, felspars, carbonates, micas, amphiboles, garnets and ore minerals, which make up about $99.9 \%$ of all the minerals recognised. Mineral content percentages for the whole of the republic (C) and for each region separately $(\mathrm{I}-\mathrm{V})$ are given in Table 2.

The proportion of the heavy fraction ( $\mathrm{sp}$. gr. $>2.89 \mathrm{~g} / \mathrm{cm}^{3}$ ) is usually small and rarely exceeds 1 percent. At the same time no particular general tendencies could be deduced as to its territorial distribution (Fig. 1).

Table 1 gives the differences in the mineralogic composition of the fine-sand $(0.1-$ $0.25 \mathrm{~mm}$ ) and aleurite fraction on the basis of 12 analyses. These differences are caused by the mechanical and chemical resistance of the minerals and by the size of the grains in the bedrock.

A number of general tendencies can be noted in the distribution of various minerais, thus creating favourable ground for the solution of stratigraphical problems. In cornection with changes in the nature of the bedrock, the carbonate content shows trend to diminish in the moraines placed farther to the south (Fig. 2), while the amounts of quartz and felspars accordingly increase. There are a great amount of pyrite in the tills situated in the vicinity of outcrops of the ground-rock, the latter being rich in pyrites (Fig. 3).

Another peculiarity which varies from region to region is the rounding of the surface nof the mineral grains. The ratio of rounding shows trend to grow larger towards the $\mathrm{S}$ and SE in general, following the movement of the Continental ice sheet and showing a similar increase in the degree of rounding to that of the grains of minerals found in the Devonian sandstones.

Most important among the minerals, from the stratigraphical point of view, are the carbonates, pyrite and the various amphiboles. Interesting results may be got by studying the distribution of the felspars, micas, pyroxenes, glauconite, zircon and tourmaline. The other minerals are either present in quantities too small to permit to make general conclusions, or are distributed evenly over the whole territory of the republic.

Academy of Sciences of the Estonian S.S,R., Institute of Geology

Received

December 30th, 1960 